\title{
道路交通騒音のうるささに及ぼす振動の影響のパス解析 A PATH ANALYSIS OF THE EFFECT OF VIBRATION ON ROAD TRAFFIC NOISE ANNOYANCE
}

\author{
佐藤哲身* \\ Tetsumi SATO
}

\begin{abstract}
The purpose of this study is to evaluate the contribution of the road traffic vibrations to the noise annoyance by using the surveyed data in Sapporo. Path analysis was used to estimate the direct and indirect effects of sixteen independent variables on noise annoyance. The principal findings are as follows : 1) The strong direct effects are for disturbance of falling asleep, bothersomeness of vibration, noise level presented by $L_{\text {eq(2) }}$ and awakening. 2) Vibration level presented by $V L_{10}$ have the strong indirect effect on noise annoyance. 3) The effect of $10 \mathrm{~dB}$ of $V L_{10}$ on the noise annoyance is equal to that of about $3.5 \mathrm{dBA}$ of $L_{\text {eq } 24}$.
\end{abstract}

Keywords : road traffic noise, road traffic vibration, annoyance, path analysis 道路交通騒音, 道路交通振動, うるささ，パス解析

\section{1.はじめに}

道路交通騒音は，都市の音環境の様態を決定づける大 きな要因となっている。道路交通騒音を評価する場合, 等価騒音レベル $\left(L_{e q}\right)$ やこれに類似した評価量を基礎 尺度として用いることが一般的であり，その有効性は広 く認められるところである。しかし, 現実の場での騷音 の評価を考えた場合, 音のエネルギー以外の要因を無視 できないことは明らかである。筆者は，前報1において， 同一発生源からの物理的刺激としての交通振動に着目し て考察を行い, 騒音のうるささに及ぼす振動の影響の存 在を確認した。本論では, その後に継続して行った調査 データを加えて総括し，この問題の定量的な評価方法の 検討を行う。

これまでに公表されてきた社会調査による騒音評価研 究では, 物理量と住民反応の関係を直接関連づける目的 で Percent Highly Annoyed ${ }^{2)}$ を算出したり，数量化理 論引などの多変量解析を用いて, 物理量を含む多数の要 因間の関連性の検討や予測を行う分析が主流を占めてき た。前者は, 騒音レベルと住民反応の直接的な対応関係 を見ることにより，実用面からの要求に答える意味で貴 重な資料を提供するものであり，後者の場合，例えば数 量化 II 類では，住民反応と各種要因の関連性の強さを比 較することで，騒音レベルを含む各種要因（主として客 観的要因）の相対的な影響の強さを検討することが可能
である。しかし，「うるささ」゙)を騷音の総合的不快感と してとらえた場合, 騒音レベルや性別・年齢などの客観 的要因のみならず，騒音による睡眠妨害・会話妨害之 いった具体的影響が「うるささ」反応に影響を及ぼして いる可能性は大いに考えられる。さらに，筆者が前報1 で得た知見に基づいて振動の影響を考慮しようとする場 合,「振動レベル」という刺激から「うるさい」という 反応を直接引き出すのは一般に無理があると思われる。 すなわち両者の間に介在する何らかの要因を見いだすこ となしに「振動レベル」と「うるささ」を結び付ける ことは論理的に無理があると言える。このように，騒音 レベル，振動レベルなどの客観的要因に端を発するうる ささ反応がどのようなプロセスによって形成されるの か, といった因果関係の定量的分析を行う方法の一つに パス解析 ${ }^{5}$ がある。パス解析は因果分析法の一つとして 社会科学の分野で広く用いられてきた手法であり，これ を騒音の評価に適用した例がいくつか報告されている。 Taylor $\left.{ }^{6}\right)$ は航空機騒音のアノイアンスをパス解析によっ て検討し，興味ある議論を展開している。我が国におい ても降旗ら ${ }^{7)}$, 泉ら ${ }^{81}$, 神成ら ${ }^{99}$ はパス解析を用いた研究 を行っており，なかでも，泉は地域比較研究(10) や複合騒 音"1なよ゙，広範なテーマに適用を試みている。

本論では, これらの研究を参考にして, 騒音に対する 住民のうるささ反応に影響を及ぼす各種要因の因果関係 
をパス解析によって検討し，その中で，振動がどのよう な役割を担い，どの程度の影響を及ぼしているかについ て考察を行う。

\section{2. 調查の概要}

本論で分析の対象とするデータは，1984，1989, 1990 年の 3 回, 札幌の広範な地区を対象として行った調查か ら得られたものである。3回の調査で選定された地区は 合計 32 で, 地区内の住戸は，道路からの距離ができる だけ等しくなるように，約 10 軒ずつ 2 3ブロックに分 類した。調查対象地区の一例を図一1に示す。このよう にして得られたブロックの総数は 94 である。調査はア ンケートレ騒音レベル・振動レベルの実測からなり，ア ンケートは訪問面接法によった。調査対象は原則として 主婦としたが, 不在の場合には, 普段家にいて一日の様 子が伺える機会の多い人に回答を求めた。また, 住戸構 造はすべて木造一戸建に限定した。アンケートの回収率 と有効回答数は表一1のとおりであり, 有効回答数は総 計 584 件にのぼっている。また, 調查票の項目中, 本論 の考察で用いる主な質問の内容を表一 2 に示す。一方, 騒音レベルと振動レベルについては, 各ブロックの屋外 に代表的且つ測定器設置可能な測定点を一か所設置し, 4 時間おき $(7,11,15,19,23,3$ 時台) に 10 分間ずつ 計 6 回, 騒音計 (RION NA-20), 振動レベル計（RION VM-14 B ) とレベルレコーダ（RION LR-04）で記録 した。騒音レベルは周波数補正回路 A 特性, 動特性 fast, 振動レベルは鉛直方面のみとし, 振動感覚補正回路を通 して記録した。このようにして記録した 10 分間ずつ 6 回, 計 60 分の騒音レベル，振動レベルの波形が 1 日の レベル変動を表わしていると仮定し， 5 秒ごと，計 720 個のレベルを読み取って；騒音・振動の各種評価尺度 ( $L_{x}, L_{\text {eq(24) }}, L_{d n}$ なよ゙) の值を計算した。以下, 混同を 避けるために，振動レベルについてはV $V L_{x}$ など, 記号 の頭に $V$ を付けて表すことにする。なお，この調査は， 道路交通を主音源とする地区を選定して実施したもので あるが，測定した騒音レベルや振動レベルの中には他の 音源や振動源によるものも含まれている可能性があり， 厳密に言えば，道路交通を主音源とする地区の環境騒

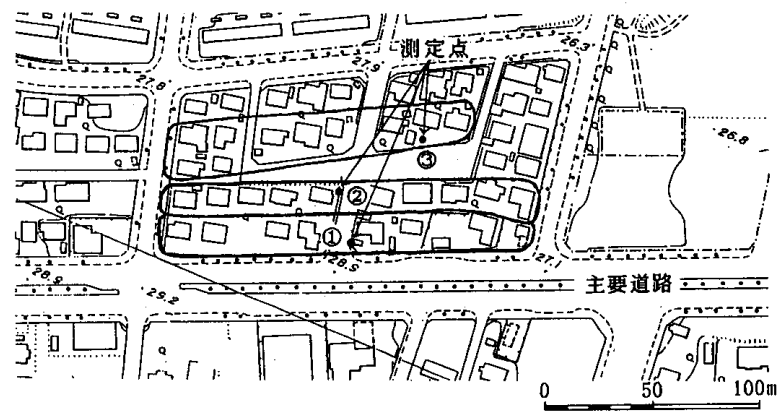

図一1 地区内住戸の分類と測定点の例
音・振動を測定したものであることを付記しておく。

\section{3. 分析の方法}

\section{1 パス解析の適用}

はじめに述べたように，騒音のうるささに関する住民 反応はよ゙のような因果関係に基づいて形成されるのか, またその反応の量はどの程度なのかを分析するために， パス解析は有効な手法であると思われる。パス解析では, 直接的, 間接的に騒音のうるささに影響を及ぼすと考え られる変数を対象として，ある変数から他の変数へ影響 の及ぶ方向にパスを設定し, 既往の研究から得られた知 見や経験に基づいて一つのモデルをつくりあげる。この パスに従って作られる回帰方程式を順次解いていくこと により，パス係数を求め，同時にパスの有意性を検討す る。最終的には，有意なパスからなる修正パスモデルを 作成し，うるささに影響を及ぼす各種要因の直接的・間 接的影響の度合いを比較検討する。なお，パス解析にお ける各々の方程式の解は, 変数を標準化した場合の回帰 分析の解に等しいので, 本論では, 田中ら ${ }^{121}$ の作成した 重回帰分析の計算プログラムを使用して, パス係数（標 準回州係数）を求めることとした。

\section{2 変数の選定と尺度構成}

パス解析における変数の選定は, モデルの基本構想の 後に続く重要な問題である。本論で用いる変数は表一2 に示す 15 の質問項目と, 騒音レベル, 振動レベルの計 17 種類であるが, これらの変数の選定について若干の 説明を加えたい。パスモデルの中で他のいかなる変数の

表-1，調查対象地区数およびアンケート回答数

\begin{tabular}{|c|c|c|c|c|}
\hline 实施年 & \multicolumn{2}{|c|}{ 対象地区数（ブロック数ま） } & \multicolumn{2}{|c|}{ 有效回答数（回収害） } \\
\hline 1984 & 札璂市 & $13(37)$ & 219 & $(70.3 \%)$ \\
\hline 1989 & 札蛽市 & $6(18)$ & 99 & $(70.5 x)$ \\
\hline 1990 & 札璂市・石狩町 & $13(39)$ & 266 & $(61.6 \%)$ \\
\hline 合 計 & & $32(94)$ & 584 & $(66.1 \%)$ \\
\hline
\end{tabular}

表一2 アンケートの主要な質問項目

\begin{tabular}{|c|c|c|}
\hline 分 類 & 項 目 & 回答用選択肢 \\
\hline \multirow[t]{5}{*}{ 個人の属性 } & 年桷 & 10 代，20代，30代，40代，50代，60代以上 \\
\hline & 性別 & 男, 女 \\
\hline & 家族数 & 1 人, 2 人, 3 人, 4 人, 5 人, 6 人以上 \\
\hline & 居住年数 & 1年末满，1-2年，2-4年，4-6年，6-8年，8年以上 \\
\hline & 職業の有無 & はい, いいえ. \\
\hline $\begin{array}{l}\text { 䮣音による } \\
\text { 具体的影響 }\end{array}$ & 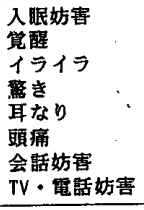 & 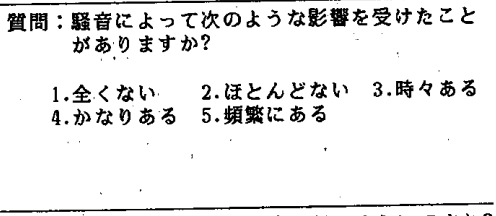 \\
\hline $\begin{array}{l}\text { 騒音に関する } \\
\text { 主算問 }\end{array}$ & うるささ & 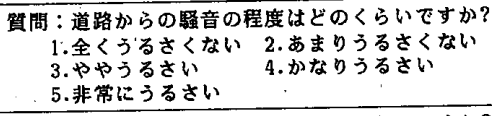 \\
\hline $\begin{array}{l}\text { 振動に関する } \\
\text { 主質問 }\end{array}$ & 気になる程度 & 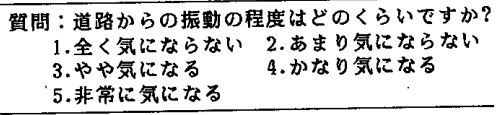 \\
\hline
\end{tabular}


影響も受けない変数を外生変数と呼ぶ。本論では騒音レ ベル，振動レベルと個人的要因をこれにあてた。選定に 当たっては既往の研究を参考にしたが，個人的要因のう ち, 主観的な要因は周囲の音環境の影響を受けて形成さ れる可能性があるので, 客観的な要因のみに限定した。 一方, 他の変数の影響を受ける変数を内生変数と呼ぶ。 本論では騒音の影響しして 8 項目の「具体的影響」を, 振動の影響として「気になる程度」をこれにあてた。こ れらの変数を選定した経緯亡「うるささ」との関係につ いては 4.3 節で詳述する。

さて, パス解析や回帰分析を行う場合, 変数は原則之 して距離尺度あるいは比率尺度の連続量でなければなら ない。アンケートで用いた質問に対する回答のほとん亡゙ は名義尺度か順序尺度の範疇に入るものであり，これら をどのように扱うかを検討する必要がある。本論で用い る変数のうち,「年齢」,「家族数」,「居住年数」,「騒音 のうるささ」,「騒音の具体的影響」,「振動の気になる程 度」は順序尺度,「性別」,「職業の有無」は名義尺度で ある。 $L_{\text {eq(24) }}$ と $V L_{10}$ を積極的に間隔尺度であるとする 理由は見あたらないが, 連続量として扱って不都合はな いと思われる。年桧についてはカテゴリーの中間の値を とって $15,25,35,45,55,65$ 歳を代表值とし, 居住年 数についても同様に $1,3,5,7,9$ 年（ただし， 1 年末満 と 1-2 年の $2 つ$ つテゴリーをまとめて 1 とした）を代 表値として，近似的に間隔尺度とみなすことにした。ま た，家族数についても「6人以上」を「6」とすること により，近似的に間隔尺度とみなすことにした。性別， 職業の有無は夕゙ミ一変数として扱い, それぞれ男に 1 , 女に 0 を, 有職に 1 , 無職に 0 を割り当てた。残りの 10 の変数はいずれも 5 段階の評定尺度であるが，これらを 間隔尺度として扱って良いか否かは議論のあるところで ある。この問題についてアッシャー5 は, いくつかの例 を示しながら肯定的な考えを述へており，筆者も 1,2 , 3, 4, 5 のカテゴリ一值を近似的に間隔尺度として扱う ことにした。なお, 各項目の評定值の平均と標準偏差を 表一3に示す。

\section{4. 考察}

4.1 騒音・振動の基礎評価尺度の選定

図一2 は, 32 地区の各ブロックにおける騒音レベル

表一3 各項目の評定值の平均・標準偏差

\begin{tabular}{|c|c|c|c|c|c|}
\hline 項 目 & 平均 & 標準偏差 & 項 目 & 平均 & 摽準偏差 \\
\hline \multirow{2}{*}{$\begin{array}{l}\text { 馶音のうるささ } \\
\text { 振動の気になる程度 } \\
\text { 入眠妨害 } \\
\text { 筧醒 } \\
\text { イライラ }\end{array}$} & \multirow{2}{*}{$\begin{array}{l}2.91 \\
2.02 \\
2.14 \\
1.93 \\
1.74\end{array}$} & \multirow{2}{*}{$\begin{array}{l}1.09 \\
1.05 \\
1.06 \\
0.99 \\
0.95\end{array}$} & $\begin{array}{l}\text { 頭痛 } \\
\text { 会铦妨害 } \\
\text { TV・電話妨害 }\end{array}$ & $\begin{array}{l}1.29 \\
1.61 \\
1.65\end{array}$ & $\begin{array}{l}0.58 \\
0.94 \\
1.02\end{array}$ \\
\hline & & & （物理量） & & \\
\hline $\begin{array}{l}\text { 謷き } \\
\text { 耳なり }\end{array}$ & $\begin{array}{l}1.78 \\
1.30\end{array}$ & $\begin{array}{l}0.99 \\
0.60\end{array}$ & $\begin{array}{l}L_{0 q(24)}, d B A \\
V L_{10}, d B\end{array}$ & $\begin{array}{l}59.3 \\
33.2\end{array}$ & $\begin{array}{l}6.76 \\
7.90\end{array}$ \\
\hline
\end{tabular}

$\left(L_{\text {eq24) }}\right)$ と振動レベル $\left(V L_{10}\right)$ の関係である。双方の 評価量に $L_{\text {eq(2) }}$ と $V L_{10}$ を採用したのは, 現在, 我が国 で用いられている変動騒音・変動振動の評価量の代表的 なものであることによる。一部の地区の $V L_{10}$ がかなり 小さな值を示しているが, これらの測定值は機器の内部 ノイズの影響を受けない範囲のものであることを確認し ている。このように調査地区全体を見ると，騒音レベル がほぼ同じ場合でも振動レベルに大きな相違のある様子 が伺える。

さて, 上述のとおり, 我が国で主に用いられる道路交 通騒音と振動の基礎評価尺度は $L_{\text {eq24) }}$ と $V L_{10}$ である。 しかし，騒音に関しては，長期間にわたって $L_{50}$ が使わ れてきたし，米国なごでは $L_{d n}$ の有効性が認められてい る。そこで, $L_{\text {eq(24) }}, L_{50}, L_{d n}$ の 3 つついて, うるさ さとの対応関係に回帰分析を適用した結果が表一 4 であ る。回帰式の当てはまりの良さを計る尺度としてよく用 いられるものの 1 つに説明率がある。説明率は, 目的変 数の平方和のうち回㛿によって説明される部分の割合を 表すもので, 数值そのものが直感的に理解しやすいとい う長所を有しているが，あるモデルが他のモデルの説明 変数を包含する場合には, 変数の多いモデルほどその值

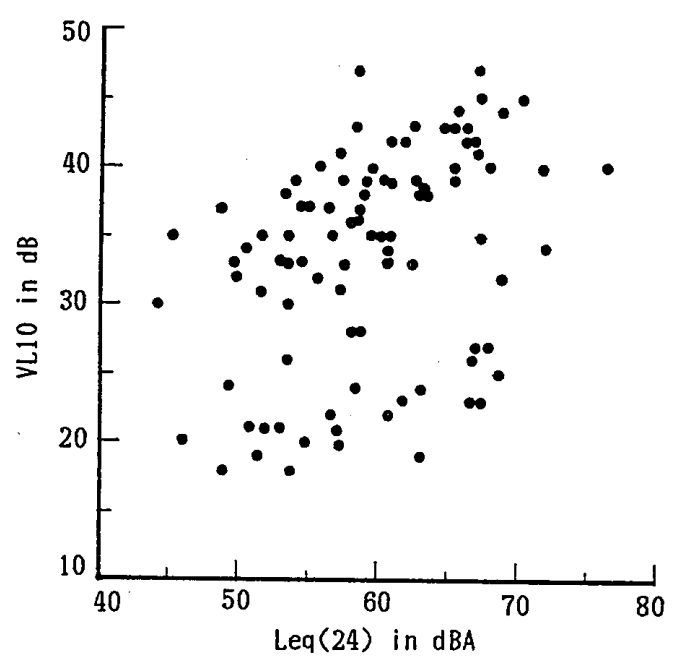

図一2 調查対象地区（全ブロック）の騒音レベルと振動レベル の関係

表一4 騒音のうるささの基礎評価尺度への回㷌

\begin{tabular}{|c|c|c|c|}
\hline 基礎評価尺度 & 回㷌式* & 锐明率 & AIC \\
\hline$L_{0} 9(24)$ & $y=0.0565 x-0.442$ & 0.124 & 1682.09 \\
\hline$L_{50}$ & $y=0.0494 x+0.342$ & 0.092 & 1703.09 \\
\hline $\mathrm{L}_{\mathrm{dn}}$ & $y=0.0532 x-0.391$ & 0.120 & 1684.82 \\
\hline
\end{tabular}

畑㷌式のyは「うるささ」を、xは基碳評価尺度を表している。

表一5 騒音のうるささの $L_{\text {eq(21) }}$ と $V L_{10}$ への回帰

\begin{tabular}{ccc}
\hline 回㷌式* & 綐明率 & AIC \\
\hline$y=0.0381 x_{1}+0.0395 x_{2}-0.659$ & 0.193 & 1636.13 \\
\hline
\end{tabular}

恛淿式のyは「うるささ」を、 $x_{1} 、 x_{2}$ はL。q(24)、VL $L_{10}$ を表し ている。 
が大きくなる性質をもっている。つまり，一般に変数の 多いモデルを高く評価する恐れがあり, 説明変数の数の 異なるモデルの精度の比較には，ある意味で公正を欠く ことになる。本論ではこの問題点を考慮して,‘モデルの 精度の比較には原則として赤池の情報量基準 $(\mathrm{AIC})^{13}$ を用い，必要に応じて説明率を併用することにする。 AIC の定義により, 数傎が小さいほよ゙当てはまりが良 いといえるので, 表一4の場合, $L_{\text {eq(24) }}$ がうるささを最 も良く説明していると解釈できる。よって，本論では， 騒音と振動の基礎評価尺度として, それぞれ $L_{\text {eq(24) }}$ と $V L_{10}$ を採用することにする。

\section{2 騒音のうるささに及ぼす騒音レベルの寄与}

振動レベルが騒音のうるささに直接影響を及ぼすこと を認めるとすれば, それは, 感覚器官の段階で何らかの 相互影響が生じているためと解釈せざるを得ない。例え ば, 振動が聴覚器官を刺激し, 聴感覚に変化を起こさせ る場合である。本論で対象としている実生活において， このような現象が起こり得ることは想像し難いが, 吉川 ら ${ }^{14)}$ の実験では，骨伝導による聴感覚への影響を認めて おり，検討の必要性はあると考える。そこで $L_{\text {eq(24) }}$ と $V L_{10}$ の 2 つ従属変数とうるささとの関係に回帰分析 を適用した結果が表一5である。 $L_{\text {eq(24) }}$ のみならず $V L_{10}$ についても標準回帰係数は正の值を示してちり，振動レ ベルが大きいほど騒音のうるささも増大することを意味 している。また，AICの数值から見て，このモデルは 表一4の騒音レベルのみによる回帰モデルよりも当ては まりの良いモデルであると言える。

\section{3 パス解析による因果関係の分析}

4.1 節および 4.2 節において，「騒音レベル」のみお よび「騒音レベルと振動レベル」によるうるささの予測 モデルを検討した。騒音のみの場合と振動を加えた場合 では，後者の方が当てはまりは良いが，説明率は $19 \%$ 程度であり，大きいとは言えない。

さて，長田 ${ }^{15)}$ は騒音によって起こる心身への影響を， 直接的特異的なものと間接的非特異的なものに分けて次 のように説明している。前者は，内耳，聴神経を経て大 脳皮質聴覚領に至る音特有の知覚経路（聴党経路）で起 こるもので，これには難聴（一時性および永久性），聴 取妨害 (マスキング)，音の感覚（大きさややかましさ） が含まれる。これらは音の直接的作用であり，音以外で は起こらない特有（特異的）な影響である。この直接的 影響に随伴して大脳の知覚領以外の領域に影響が及ぶ と, 情緒影響 (不快, 焦燥, 怒り, 憂うつなど), 生活 妨害（仕事，勉学，休養，睡眠など）が起こり，さらに 身体的影響 (循環器, 消化器, 内分泌器など) が起こる が,これらは音以外の環境刺激 (低温, 高温, 振動など) や人間のトラブルなどおよそストレスと呼ばれる様々な 原因でも起こる非特異的な影響である。以上の騒音の直
接的，間接的影響が総合されてアノイアンス（迷惑感, 邪魔感，わずらわしさ）が生じる。すなわち，アノイア ンスは感覚, 情緒, 生活, 身体への影響の総体が引き起 こす被害感であり，単なる情緒的不快感ではなく，騒音 に敵対する心理的な姿勢，態度 (attitude) であるとし ている。筆者はこの説を基本的に支持するものであるが, 騒音のアノイアンスに対応する訳語として，「うるささ」 をあてている。「うるささ」と「アノイアンス」の対応 関係については議論のあるところであるが16)，筆者は， 社会調査によって実生活の場での「うるささ」を尋ねた 場合，その用語が地域で一般に使用されている限り，総 合的な意味での不快感すなわちアノイアンス反応が得ら れるのではないかと考えている。「うるささ」に関する 質問は,騒音による具体的影響の質問の後に設定したが， 質問文は表一 2 に示すとおり簡潔なもので，特別な説明 は一切行っていない。

長田の説を参考として因果関係を考慮し，筆者の行っ た調査項目中，表一2に揚げた主要な項目をアローダイ アグラムで示したパスモデルが図一3である。振動レベ ルは外生変数として扱い,「振動の気になる程度」とい う内生変数を介して「うるささ」と結びつけることによ り，論理的に無理のない仮説をたてるとともに，振動と いう音以外の刺激による間接的影響を「騒音源」（長田 は「騒音」としている) に敵対する心理的な姿勢という 立場でモデルに組み入れた。他の項目に関しては，外生 変数として騒音レベル，および回答者個人にかかわる項 目を設定した。また, 内生変数としては騒音による直接 的, 間接的影響に関する項目を説定した。騒音の影響に 関する項目中, 「入眠妨害」と「覚醒」,「耳なり」と「頭 痛」,「会話妨害」と「TV・電話妨害」は, それぞれ「睡 眠妨害」,「耳なりや頭痛」,「聴取妨害」という形でまと めることが可能であり, モデルの単純化や説明変数の独 立性の観点からその方が望ましいとする考え方もあろ う。筆者がそのような方法をとらずに全項目を採用した のは, 騒音の程度や個人の性質, あるいはその場の状況 によって，類似した項目であっても，必ずしも反応が一 致しないケースが容易に想像できるからである。表一6 は，図一3のアローダイアグラムから得られた回帰方程

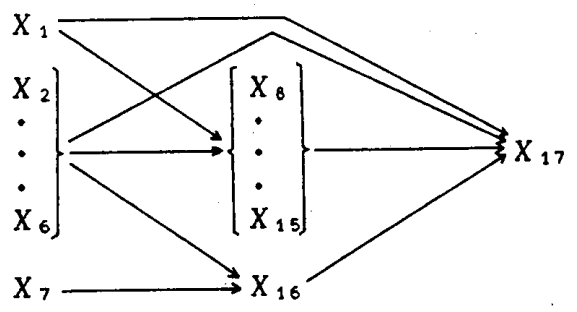

$X_{1}$ : 騒音レベル, $\mathrm{L}_{\text {のq (24) }}$

$X_{2} \sim X_{6}$ :個人の属性

$X_{7}$ :振動レベル, $V_{10}$ $X_{8} \sim X_{15}$ : 騒音による具体的影篦 $X_{16}$ :振動の気になる程度 $X_{16}:$ :振動の騒音のうるささ

図一3 道路交通騷音のうるささに関するパスモデル 


\begin{tabular}{|c|c|c|c|c|c|c|c|c|c|c|c|c|c|c|c|c|c|}
\hline \multirow{2}{*}{ 目的 } & \multirow[b]{2}{*}{$x_{1}$} & \multirow[b]{2}{*}{$x_{2}$} & \multirow[b]{2}{*}{$x_{3}$} & \multirow[b]{2}{*}{$x_{4}$} & \multirow[b]{2}{*}{$x_{5}$} & \multirow[b]{2}{*}{$x_{6}$} & \multirow[b]{2}{*}{$x_{7}$} & \multicolumn{2}{|c|}{ 説明変数 } & \multirow[b]{2}{*}{$x_{10}$} & \multirow[b]{2}{*}{$x_{11}$} & \multirow[b]{2}{*}{$x_{12}$} & \multirow[b]{2}{*}{$x_{13}$} & \multirow[b]{2}{*}{$x_{14}$} & \multirow[b]{2}{*}{$X_{15}$} & \multirow[b]{2}{*}{$x_{16}$} & \multirow{2}{*}{$\begin{array}{l}\text { 回㷌の } \\
\text { 有意性 }\end{array}$} \\
\hline & & & & & & & & $x_{8}$ & $X_{9}$ & & & & & & & & \\
\hline$x_{B}$ & $.106^{* *}$ & $.079^{\mathrm{NS}}$ & $-.139^{* * *}$ & $-.012^{\mathrm{NS}}$ & $-.017^{\mathrm{Ns}}$ & $.126^{* *}$ & - & - & - & - & - & - & $\therefore$ & - & . & $\therefore$ & 粎 \\
\hline$x_{9}$ & $.143^{* *}$ & $.149^{* *}$ & $-.116^{* *}$ & $-.020^{\mathrm{Ns}}$ & $-.019^{\mathrm{NS}}$ & $.086^{*}$ & - & - & - & - & . & 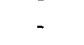 & - & - & - & - & ** \\
\hline$x_{10}$ & $.082^{*}$ & $.093^{*}$ & $-.012^{\mathrm{NS}}$ & $-.016^{\mathrm{NS}}$ & $-.064^{\mathrm{NS}}$ & $.044^{\mathrm{NS}}$ & - & - & - & - & - & - & - & - & - & - & NS \\
\hline$x_{11}$ & $.133^{* *}$ & $.086^{\mathrm{NS}}$ & $-.063^{\mathrm{Ng}}$ & $.011^{\mathrm{Ng}}$ & $-.064^{\mathrm{NS}}$ & $.012^{\mathrm{Ns}}$ & - & - & - & - & - & - & - & - & - & - & $*$ \\
\hline$x_{12}$ & $.102^{*}$ & $.082^{\mathrm{Ns}}$ & $-.031^{\mathrm{NS}}$ & $-.003^{\mathrm{NS}}$ & $-.019^{\mathrm{NS}}$ & $.041^{\mathrm{NS}}$ & - & - & - & - & - & . & - & - & - & - & NS \\
\hline$x_{13}$ & $.099^{*}$ & $.073^{\mathrm{NS}}$ & $-.027^{\mathrm{NB}}$ & $.020^{\mathrm{NS}}$ & $-.033^{\mathrm{Ng}}$ & $.032^{\mathrm{Ns}}$ & - & - & . & - & - & - & - & - & - & - & NS \\
\hline$x_{14}$ & $.270^{* *}$ & $.063^{\mathrm{Ns}}$ & $-.110^{* *}$ & $.032^{\mathrm{NS}}$ & $.069^{\mathrm{NS}}$ & $.074^{\mathrm{NS}}$ & - & - & - & - & - & - & - & . & - & - & ** \\
\hline$x_{15}$ & $.314^{* *}$ & $.063^{\mathrm{NS}}$ & $-.100^{*}$ & $.062^{\mathrm{Ns}}$ & $.056^{\mathrm{Ns}}$ & $.063^{\mathrm{NS}}$ & - & - & - & $\cdots$ & - & - & . & - & - & - & * \\
\hline$x_{16}$ & & $.011^{N S}$ & $-.080^{*}$ & $-.028^{\mathrm{NS}}$ & $.155^{* *}$ & $.087^{*}$ & $.410^{* *}$ & - & & & - & - & - & - & - & & ** \\
\hline $\begin{array}{l}X_{17} \\
R^{2}(\end{array}$ & 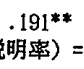 & $\begin{array}{l}.009^{N S S} \\
543, \text { Al }\end{array}$ & $\begin{array}{c}.017^{\mathrm{NS}} \\
C=1330.4\end{array}$ & $-.004^{\mathrm{NS}}$ & $-.005^{\mathrm{NS}}$ & $.005^{\mathrm{NS}}$ & - & $.257^{* *}$ & $.131^{* *}$ & $.087^{\mathrm{Ns}}$ & $-.006^{\mathrm{N} s}$ & $-.074^{\mathrm{NS}}$ & $-.077^{\mathrm{Ns}}$ & $.136^{*}$ & $.108^{*}$ & $.235^{* *}$ & ** \\
\hline
\end{tabular}

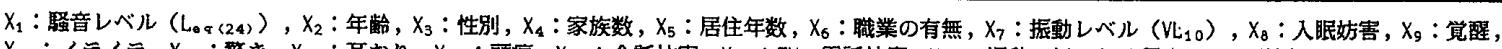

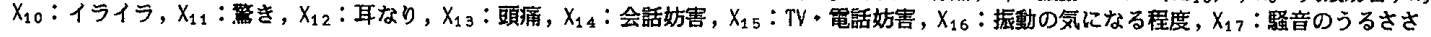

\section{表一7 道路交通騒音のうるささに及ぼす各種要因の効果}

\begin{tabular}{|c|c|c|c|}
\hline 説明变数 & 直接効果 & 間接効果 & 総合勃果 \\
\hline 騒音レベル， Leq (24)（ $\left.X_{1}\right)$ & .191 & .108 & .299 \\
\hline 年齢 $\left(X_{2}\right)$ & .009 & .054 & .063 \\
\hline 性別 $\left(X_{3}\right)$ & .017 & -.092 & -.075 \\
\hline 家族数 $\left(X_{4}\right)$ & -.004 & -.004 & -.008 \\
\hline 居住年数（ $X_{5} ）$ & -.005 & .044 & .039 \\
\hline 職業の有無 $\left(X_{6}\right)$ & .005 & .079 & .084 \\
\hline 振動レベル，VL & - & .096 & .096 \\
\hline 入眠妨害 $\left(X_{B}\right)$ & .257 & - & .257 \\
\hline 覚醒 $\left(\bar{X}_{9}\right)$ & .131 & - & .131 \\
\hline イライラ $\left(x_{10}\right)$ & .087 & - & .087 \\
\hline 慗き $\left(x_{11}\right)$ & -.006 & - & -.006 \\
\hline 耳なり $\left(X_{12}\right)$ & -.074 & - & -.074 \\
\hline 頭痛 $\left(X_{13}\right)$ & -.077 & - & -.077 \\
\hline 会話妨害 $\left(X_{14}\right)$ & .136 & - & .136 \\
\hline TV・電話妨害 $\left(X_{15}\right)$ & .108 & - & .108 \\
\hline 振動の気になる程度（ $x_{16} ）$ & .235 & - & .235 \\
\hline
\end{tabular}

式を解いて，変数を標淮化した時の回帰係数，すなわち パス係数を求めたものである。「うるささ」に直接効果 をもたらす変数は，図一3において直接パスでつながっ ている変数であり, 内生変数を介してつながっている変 数は間接効果をもたらす変数である。直接効果の大きさ はパス係数そのものであり，間接効果の大きさは，外生 変数から内生変数に至るパス係数上内生変数からうるさ さに至るパス係数の積で表される。また，直接効果と間 接効果の和を全効果という。表一7 はこれらの値を示し たものである。この表より, 直接効果の大きな変数は「入 眠妨害」,「振動の気になる程度」,「L $\left.L_{e q(24)}\right\rfloor$, 間接効果の 大きな変数は「 $\left\lceil L_{e q(24)}\right\rfloor,\left\lceil V L_{10}\right\rfloor$, 「性別」, 全効果の大 きな変数は「L $L_{\text {eq(24) }}$,「入眠妨害」,「振動の気になる程度」 であることがわかる。 $L_{\text {eq(24) }}$ のみならす $V L_{10}$ も正の効 果を示しており，「振動レベル」が大きいほよ゙「気にな る程度」は強く,「うるささ」も増大すると解釈できる。 なお，このモデルの AIC 值 (1330.46) と説明率 (0.543) を見ると, 騒音レベルのみ, あるいは騒音レベルと振動 レベルによるモデルに比べて, かなり精度の良いモデル であることがわかる。

\section{4 修正パスモデルの提案と意義}

前節のパスモデルによって, 対象とした全変数の効果 の大要を知ることができるが，この中にはパス係数が有

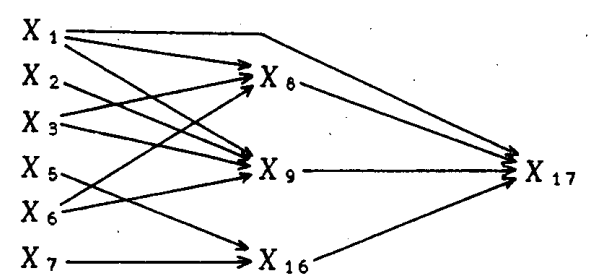

\begin{tabular}{|c|c|}
\hline $\begin{array}{l}X_{1}: \text { 騒音レベル, Leq(24) } \\
X_{2}: \text { 年齡 } \\
X_{3}: \text { 性別 } \\
X_{5}: \text { 居住年数 } \\
X_{6}: \text { 職業の有無 }\end{array}$ & 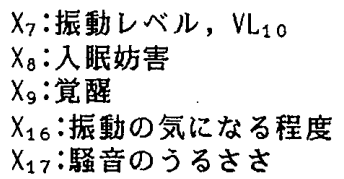 \\
\hline
\end{tabular}

図-4 修正パスモデル

意でない変数も含まれている。そこで，これらの変数を 除いた新たなモデルを考えることにより，簡潔で明快な モデルを構築できる可能性がある。表一6で有意水準 $5 \%$ 以上の有意な変数をとりあげて同様な分析を行っ た結果, 新なにパス係数が有意でない変数の存在が認め られたので, 再度, 有意な変数のみによる分析を行った。 最終的に得られたモデル（修正パスモデル）は図一4の とおりである。この修正モデルでは, 初期モデルで有意 であった「会話妨害」と「TV・電話妨害」という聴取 妨害に関する $2 つ の$ 変数が欠落している。これは, 上述 の通り, 最終的な修正モデルに至る計算過程でパス係数 が $5 \%$ 水準で有意とならなかつたことにるものであ る。ただし, 筆者はこの結果から, うるささと聴取妨害 を別個の騒音影響と捉えるのではなく，修正モデルにお ける他の要因よりもうるささに対する寄与が小さいもの と解釈している。なお，これらの変数は 10～20\% 水準 でみると有意であるが，この分野の研究では $5 \%$ 水準 を判断のよりどころとするのが一般的であるので, 本論 文においても同じ基準を設定することとした。なお， AIC 值 (1348.40) および説明率 $(0.510)$ は, 修正前 のモデルに比べて，ほとんど遜色のないものとなってい る。また, 表一8は修正パスモデルの直接効果, 間接効 果および全効果である。さて，具体的な効果を数量的に 考えてみよう。表一8の数値を用いることにより，一定 量の「うるささ」の増加に寄与する各変数の值を比較す 
表一8 修正パスモデルにおける各種要因の効果

\begin{tabular}{|c|c|c|c|}
\hline 説明変数 & 直接効果 & 間接効果 & 總合効果 \\
\hline $\begin{array}{l}\text { 騒意レベル, Loq(24) }\left(X_{1}\right) \\
\text { 年齢 }\left(X_{2}\right)\end{array}$ & .230 & $\begin{array}{l}.057 \\
.025\end{array}$ & $\begin{array}{l}.287 \\
.025\end{array}$ \\
\hline 性別 $\left(X_{3}\right)$ & - & -.059 & -.059 \\
\hline 居住年数 $\left(X_{5}\right)$ & - & .044 & .044 \\
\hline 職業の有無 $\left(X_{6}\right)$ & - & .051 & .051 \\
\hline 振動レベル, $V L_{10}\left(X_{7}\right)$ & - & .116 & .116 \\
\hline 人眠妨害 $\left(X_{8}\right)$ & .310 & - & .310 \\
\hline 覚醒 $\left(X_{9}\right)$ & .172 & - & .172 \\
\hline 振動の気になる程度 $\left(X_{16}\right)$ & .285 & - & .285 \\
\hline
\end{tabular}

ることが可能である。例えば, $L_{\text {eq24) }}$ の標準偏差 1 単位 の変化は,「うるささ」に標準偏差 0.230 単位の直接効 果と 0.057 単位の間接効果, および 0.287 単位の全効果 をもたらすと解釉できる。他の変数も同様に扱うことが できるので相互比較が可能である。ここで, 本論の目的 である騒音のうるささに及ぼす振動の影響について考察 を加えたい。「うるささ」を標準偏差で計って 1 単位変 化させるためには $L_{\text {eq(24) }}$ を $(1 / 0.287=) 3.48$ 単位変化 させる必要があり， $L_{\text {eq24) }}$ の標準偏差が $6.76 \mathrm{dBA}$ (表 -3 参照) であることから，この值は $(3.48 \times 6.76=)$ $23.5 \mathrm{dBA}$ に等しい。同椂に，「うるささ」を標準偏差 で 1 単位変化させるためには $V L_{10}$ を $(1 / 0.116=) 8.62$ 単位変化させる必要があり, 表一 3 の標準偏差 $(7.90 \mathrm{~dB})$ よりこの值は $(8.62 \times 7.90=) 68.1 \mathrm{~dB}$ に等しい。よって, $V L_{10}$ の $68.1 \mathrm{~dB}$ の変化は $L_{\text {eq } 24}$, の $23.5 \mathrm{dBA} の$ 変化に 等価な「うるささ」の変化をもたらすと解釈できる。こ れを単純な比で表すと， $V L_{10}$ の $10 \mathrm{~dB}$ が $L_{\text {eq(24) }}$ の約 $3.5 \mathrm{dBA}$ に匹敵することになる。また，「振動の気にな る程度」の標準偏差 1 単位の変化は「うるささ」の 0.285 単位の変化をもたらすこともわかる。「入眠妨害」, 「覚醒」も「うるささ」に重要な効果をもたらす要因で はあるが，同時に，振動の影響も重要な意味を持ってい ることがわかる。以上のことは，道路交通騒音のうるさ さに関して社会調査を行う場合, 何らかの形で振動の影 響を考慮する必要があることを意味するものと言える。

\section{5.おわりに}

以上，道路交通騒音のうるささに及ぼす振動の影響に ついて検討を行い, パスモデルを提案した。

以上をまとめると, 以下のとおりである。

(1) 道路交通騒音のうるささに及ぼす振動の影響を検討 する場合，パス解析は有効な手法の一つであると言え る。

(2) 道路交通騒音のうるささに影響を及ぼす要因のう ち,「騒音レベル」,「入眠妨害」,「覚醒」之並んで,「振 動」の重要性が明らかとなった。

(3)「振動レベル」が大きくなるほよ゙「気になる程度」 は強くなり，その結果，「うるささ」も増大する。

(4) 道路交通騒音のうるささに及ぼす $V L_{10}$ の $10 \mathrm{~dB} の$
効果は, $L_{\text {eq(24) }}$ の約 $3.5 \mathrm{dBA}$ の効果に等価である。 おわりに，本論をまとめるにあたり，貴重なご助言を いただいた室蘭工業大学・泉 清人教授と, 調査・分析 にご協力いただいた多数の北海学園大学学生諸君に謝意 を表する。

\section{参考文献}

1）佐藤哲身：交通騒音のうるささに及ぼす振動の影響の有 無, 日本建筑学会計画系論文報告集, 第 427 号, pp. 1 7, 1991

2) Schultz, T. J. : Community Noise Rating, Second Edition, Applied Science Publishers, pp. 245 247, 1982

3）西宮 元：騒音・振動に関する社会反応とその特徵につ いて, 日本音響学会誌, Vol. 32, No.3, pp. 147 155, 1976

4）泉 清人：騒音の心理的不快感に関する属性についての 考察, 日本建築学会北海道支部研究報告集, No. 46, pp. 35 38, 1976

5） H. B.アッシャー (広瀬弘忠訳)：因果分析法, 朝倉書店, 1980

6) Taylor, S. M. : A Path Model of Aircraft Noise Annoyance, J. Sound Vib., Vol.96, No.2, pp. 243 260,1984

7）降旗建治，柳沢武三郎：騒音のうるささに関するパスモ デルによる評価一鉄道騒音と自動車騒音との比較検討, 電子情報通信学会技術研究報告 (EA 87-50), Vol.87, No. 221, pp. $41 \sim 48,1987$

8）泉 清人：自動車騒音の住民反応に関する社会調查（登 別市), 日本音響学会騷音研究会資料, N-90-28, 1990

9）神成陽容, 金安公造：都市生活空間における騒音暴露と 住民の主観評価に関する研究 (その 2 空間別騒音レベ 儿と住民反応の因果関係), 日本音響学会騒音研究会資料, $\mathrm{N}-91-34,1991$

10）泉 清人, 矢野 隆, 山下俊雄：道路交通騒音に関する 住民反応の地域比較研究 $(1), 1991$ 年度日本建築学会 大会学術講演梗概集（東北）, 環境工学, pp. 443 444, 1991

11）高橋弥生, 泉 清人：鉄道と自動車の複合騒音の社会反 応に関する研究, 1991 年度日本建築学会大会学術講演梗 概集 (東北)，環境工学，pp. 445 446, 1991

12）田中 豊, 垂水共之, 脇本和昌：パソコン統計解析ハン ドブック ( II 多変量解析編), 共立出版, pp.11 15, 1984

13）赤池弘次：情報量基準 AIC とは何吕, 数理科学, No. 153, pp. 5 11, 1976

14）吉川昭吉郎，佐野和久，佐藤達哉：ラウドネスに対する 振動の寄与, 日本音響学会聴覚研究会資料, H-86-42, pp. 1 8, 1986

15）長田泰公：騒音のうるささ，騒音制御，Vol. 13，No.4, pp. $3 \sim 6,1989$

16）日本音響学会関西支部：パネルデイスカッション Loudness, noisiness, annoyance 趈って, 日本音響学会騒 音研究会資料, 1980

（1991 年 11 月 10 日原稿受理, 1992 年 6 月 30 日採用決定） 